\title{
Anxiolytic activity of tomato juice on animal model
}

\begin{abstract}
Tomato is an excellent fruit and can make people healthier reducing the risk of many diseases such as cardiovascular diseases, obesity, osteoporosis and cancer. The aim of the study is to evaluate the anxiolytic activity of tomato juice in animal model. Lycopene, present in tomatoes is thought to possess anxiolytic activity.

Albino wistar mice were divided in three groups. Group I was considered as control group and given distill water. Group II was given low dose of tomato juice i.e. $10 \mathrm{ml} /$ $\mathrm{kg}$, group III received high dose of tomato juice i.e., $30 \mathrm{ml} / \mathrm{kg}$. All animals were given ad libitum diet and follow standard guidelines. The anxiolytic activity were evaluated with help of different models of anxiety such as head dip, open field, elevated plus maze and cage crossing apparatus. Our results showed positive anxiolytic effects. We concluded that tomato juice possesses positive anxiolytic effects due to presence of lycopene.
\end{abstract}

Keywords: anxiolytic, head-dip, lycopene and tomato juice
Volume 7 Issue 2 - 2018

Sana Sarfraz, Sidra khan, Zarnab Augustine, Hira Raees, Rabia Arif, Kiran Saeed

Faculty of Pharmacy, Jinnah University for Women, Pakistan

Correspondence: Sana Sarfraz, Faculty of Pharmacy, Jinnah University for Women, Karachi-74600, Pakistan, Email sana.sarfraz@live.com

Received: January 15, 2018 | Published: April 27, 2018
Abbreviations: GABA, gama amino butyric acid; MAOI, mono amino oxidase inhibitor's; ODA, octa denoic acid; SSRI, selective serotonin reuptake inhibitors; TG, triglyceride

\section{Introduction}

Anxiety belongs to mental disorder in which patient feels fear and remains worried about their future events. ${ }^{1}$ To diagnose anxiety it is essential that symptoms need to be present for at least six months. ${ }^{2}$ Whenever anyone feels anxious, besides them, most of the individuals become nervous, whenever they start the new work, they take decision and at the same time get worried. There are many types of anxiety disorder that may interfere with the normal lifestyle of any individual. ${ }^{3}$ The severe anxiety disorder leads to the abnormal sensation at the time of any occasion. Overall anxiety has become more common illness, about one in three women and one in five men feel anxiety in their life. ${ }^{4}$ In generalized anxiety disorder excessive tension for longer time of period is experienced by patients. This is characterized by muscle tension, irritability, fatigue, worries and sleep problems. In panic disorder patient may feel repeatedly unexpected panic attacks, which suddenly appear and are very intense characterized by palpitation, increase in heart rate, sweating, shortness of breath, fears and worries. In social phobia person feels nervousness from the social environment and feel embarrassment and fear. ${ }^{5}$ Phobia is characterized by fear of anything that is not dangerous in real life. Post traumatic stress disorder is characterized by anger, distraction, severe depression, it may be from traumatic events like; natural disasters and wars. Social anxiety disorders are characterized by severe depression, embarrassment and fear. It may result from environmental effects and also from social environment. ${ }^{6}$ Standardized clinical questionnaires such as Taylor Manifest Anxiety Scale or else Zulf Self Rating Anxiety Scale is used for revealing anxiety based on symptoms. ${ }^{7}$

Neurotransmitter dysregulation is the cause of anxiety in which there is reduced level of Gama amino butyric acid (GABA). ${ }^{8}$ Further reason of anxiety is interruption of neuronal circulation in amygdala which deals with fear and emotions. Selective serotonin reuptake inhibitors (SSRI) and mono aminooxidase inhibitors (MAOI) are commonly used medications in anxiety. ${ }^{9}$
Solanum lycopersicum is the scientific name of tomatoes and it belongs to family Solanaceae. Tomato is a fruit which is encumbered with all kinds of benefits. Lycopene (antioxidant) is the most important content present in tomatoes. Tomato is enriched with phosphorus, magnesium, potassium and Iron so necessary for the normal activity of nerves and muscles. It contains Vitamins such as A, B and C. Further it contains phytosterols that plays key role to control cholesterol. It has immense deal of vitamin $\mathrm{A}$ and $\mathrm{C}$, these vitamins counteract detrimental free radicals in the blood to work as antioxidants. It is also good for kidneys, eyes and heart. It contains large amount of chromium an important mineral which sufficiently control the level of blood sugar to control diabetes. Oxalic acid content in tomatoes is responsible for the formation of insoluble calcium salts which can precipitate as kidney stones. Tomato is acidic in nature, high consumption is not recommended in gastro duodenal disease. ${ }^{10}$

Tomato juice is extracted from tomatoes. It is globally cultivated as a fleshy fruit and is famous for its nutritive value. A study showed that there was 93 to 95 percent of water content found in tomatoes and 5.5 to 9.5 percent of solid matter was found. Tomato juice was primarily composed of lignin-cellulose and pectin. ${ }^{11}$

It was highlighted in the study that the contents present in the tomato-based food products helped in preventing diseases. The ingredients found in the tomato juice were beneficial for the women of middle age, for example, women with cardiovascular issues and women with the symptoms of menopause. Bioactive ingredients were found in tomato juice such as gamma-aminobutyric acid (GABA), esculeoside A, lycopene, 11-octadecadienoic acid (13-oxo-ODA) and $13-$ oxo-9. ${ }^{12}$ These ingredients were found to be beneficial for the health of middle-aged women, such as, blood pressure. Lycopene found in tomato juice behaved as an anti-cancer and anti-oxidant. It also showed a significant effect on lowering of heart rate and serum TG level. ${ }^{12}$

Lycopene present in tomatoes and tomato juice behaved as a cancer-fighting agent; it has the effect of detoxification in the body. Vitamin $\mathrm{C}$ present in tomato juice helped in healing the sunburns and also helped in restoring the fatigue from the body. Research has found 
that lycopene present in tomato juice can help older people in staying active and healthier for long period. ${ }^{10}$

The literature review shows that tomato is one of the most important fruit in our lives and it has much significance on health so its proper consumption is important. Present study was designed to evaluate the effect of tomato juice on anxiety models.

\section{Materials and methodology}

\section{Experimental animal}

Current studies have been carried on albino mice of both (sex male and female) possessing weight ranging from 18-24 gm. They were bred and housed in Animal house of Jinnah University for Women. All animal groups were reserved under proper environmental conditions and maintained at temperature of $23 \pm 2^{\circ} \mathrm{C}$. Furthermore the animals were provided food and water ad libidum.

\section{Material}

In the present study fresh tomatoes were procured from local market in Karachi, Pakistan and were identified by Department of Pharmacognosy, Faculty of Pharmacy Jinnah University for Women. The tomatoes were then peeled off, cut into pieces, blended and juice was filtered.

\section{Dosing and grouping}

As per dosing, animals were divided in three groups each group having 6 animals. Group I was termed as Control and given distill water, Group II was termed as treated I and received low dose $10 \mathrm{ml} /$ $\mathrm{kg}$, while Group III was termed as treated II which received high dose i.e., $30 \mathrm{ml} / \mathrm{kg}$. ${ }^{13}$

\section{Head dip test}

Head Dip Test also called as Hole Board method is utilized for the recognition of anxiety. This method comprises of an enclosed wooden rectangular shape box $(35 \times 45 \times 45 \mathrm{~cm}) .{ }^{14}$ Before starting the experiment the mice should be adapted with overall environmental conditions in which head board apparatus is to be placed. The mice were placed in the position maintaining centre area and allowed movement for 5 minutes. For evaluation of result, the number of times the mouse stuck out its snout was noted. At the end of experiment apparatus was washed off with $70 \%$ alcohol. $^{15}$

\section{Open field test}

In Open field test, the apparatus comprises of square shape chamber along with $42 \mathrm{~cm}$ high walls. While the floor of square shape chamber marked in to middle area of open field may also be present as $15 \times 15 \mathrm{~cm}$ in central square portion. This test is usually carried out to assess the emotional behavior in rodents. It may also be used to assess locomotor as well as exploratory activity in rodents. ${ }^{16}$

For conduction of this test the mouse was placed by the help of tail in the centre position of field. The behavior of mouse was noted on the basis of times the mouse moved in peripheral squares for 5 minutes. After completion of experiments clean-up of apparatus was carried out to remove debris and body odor of rodent by using $70 \%$ alcohol.

\section{Light and dark test}

It is another test for identification of anxiety behavior in rodents. This test was designed by Crawley Goodwin. Mostly rodents usually favor dark areas. The major step involved in this apparatus is that the chamber is allocated in to two compartments. One is the dark compartment located at the second half having small aperture $(13 \times 5 \mathrm{~cm})$ covered by lid and painted black.

To start the experiment, the mice were familiarized with surrounding environment where the apparatus was placed. Each mouse was placed individually in the centre of the brightly illuminated compartment. Furthermore, the mouse was allowed to move freely from one (light) compartment to another (dark) compartment. The time spend in the light compartment was noted for 5 minutes. ${ }^{17}$

\section{Elevated plus maze}

Elevated plus Maze was utilized to assess anxiety in animal model which is based on open space and usually consist of near vertical surfaces (thigmotaxis) behaviour in rodents. According to the name plus maze shape apparatus comprises of two portions in which one part consists of two open arms and other involves two closed arm elevated $40-70 \mathrm{~cm}$ from floor. The mice were acclimatized and placed gently in the centre position of maze. Record the time spent by the mice in open arms for 5 minutes. ${ }^{18}$

\section{Results and discussion}

For the analysis of results SPSS tool version 19 was used. First means of all tests were taken and then mean was compared with the control value. Two-way ANOVA was applied followed by post hoc Tukeys test. The result was significant if $p$ was $\leq 0.01$, if value of $p$ was $\leq 0.001$ it was considered more significant result while if $p$ was $\leq$ 0.0001 it was highly significant result.

Now a day's people prefer herbal and natural products for curing the disease. Herbal products have negligible side effects as compared to conventional dosage forms. In this study we observed the anxiolytic effects of tomato juice on mice. The anxiolytic activity of tomato was thought to be due to the presence of its active constituent lycopene. We have studied the anxiolytic activity of tomato juice in mice by the help of different models of anxiety such as experimental setup of head dip, open field, elevated plus maze and cage crossing apparatus.

When mice were placed in head dip apparatus, they showed maximum head dip at baseline indicating anxiety has developed in them, when the rodents were given daily dosing of tomato juice the number of head dips decreased gradually. Table 1 and Figure 1 showed that at increased dose tomato juice showed highly significant anxiolytic activity as compared to low dose.

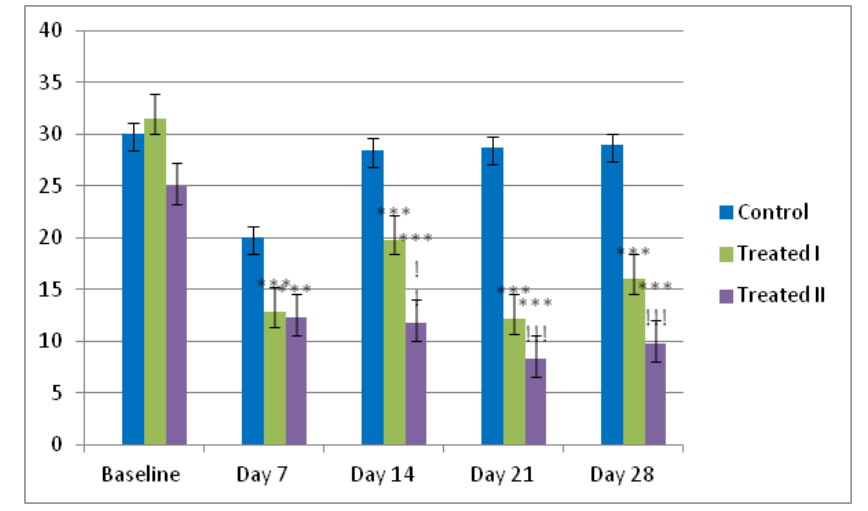

Figure I Activity of tomato juice on head-dip activity. 
Rodents like mice and rats have natural repugnance on bright areas They prefer to stay in holes and corners. The theory of this test was when animal was placed in the apparatus so it feels fear in open field and prefers to stay at corner. Dosing with anxiolytic preparation led to increased movement in Central Square and reduction in movement in the peripheral square crossings. Results have been shown in Table 2 and Figure 2.

The elevated plus $(+)$ maze test is also used to define the anxiety level in mice or rats. Rodents when placed in this apparatus they prefer to stay more time in closed end due to fear or development of anxiety but after the administration of anxiolytic drug, they spent more time in open area. Table 3 and Figure 3 showed increase in time duration spent in open arm by both doses and further confirm our above results that increasing the dose increases the anxiolytic activity.

This test has same principle as that of open field apparatus. When animal was placed in square box it got agitated and it continuously tried to find route to escape. But after the administration of tomato juice it became less agitated and its movement also decreased. According to Table 4 and Figure 4 it was noted that our results are highly significant.

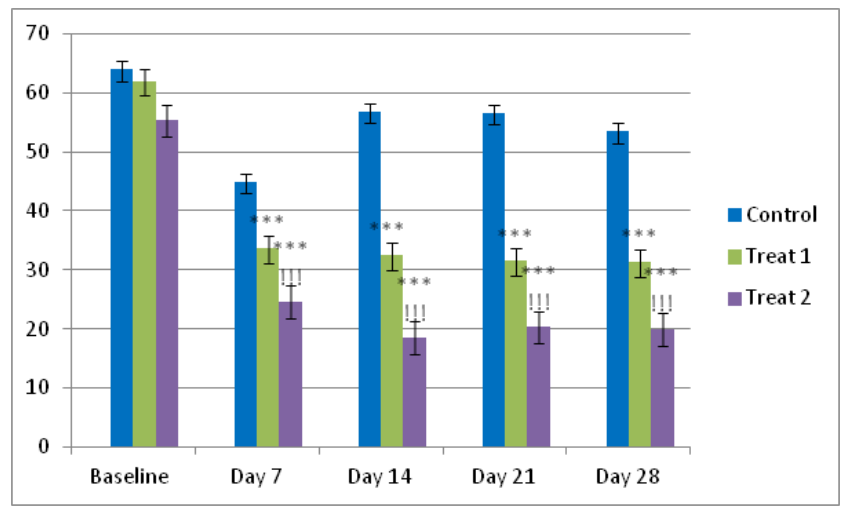

Figure 2 Activity of tomato juice on open field.

Table I Activity of tomato juice on head-dip test

\begin{tabular}{llllll}
\hline Groups & $\begin{array}{l}\text { Baseline } \\
\text { Mean } \pm \text { SD }\end{array}$ & $\begin{array}{l}\text { Day 7 } \\
\text { Mean } \pm \text { SD }\end{array}$ & $\begin{array}{l}\text { Day 14 } \\
\text { Mean } \pm \text { SD }\end{array}$ & $\begin{array}{l}\text { Day 21 } \\
\text { Mean } \pm \text { SD }\end{array}$ & $\begin{array}{l}\text { Day 28 } \\
\text { Mean } \pm \text { SD }\end{array}$ \\
\hline Control & $30.0 \pm 1.1$ & $20 \pm 1.8$ & $28.5 \pm 1.7$ & $28.67 \pm 1.5$ & $29 \pm 1.6$ \\
Treated I & $31.5 \pm 2.4$ & $12.83 \pm 2.3^{* * *}$ & $19.83 \pm 1.9^{* * *}$ & $12.17 \pm 1.6^{* * *}$ & $16 \pm 1.4^{* * *}$ \\
Treated II & $25 \pm 2.2$ & $12.33 \pm 1.7^{* * *}$ & $11.83 \pm 2.3^{* * * ! ! !}$ & $8.33 \pm 1.2^{* * * !}$ & $9.83 \pm 1.8^{* * * ! ! !}$ \\
\hline
\end{tabular}

Table 2 Activity of tomato juice on open-field test (peripheral squares)

\begin{tabular}{llllll}
\hline Groups & $\begin{array}{l}\text { Baseline } \\
\text { Mean } \pm \text { SD }\end{array}$ & $\begin{array}{l}\text { Day 7 } \\
\text { Mean } \pm \text { SD }\end{array}$ & $\begin{array}{l}\text { Day 14 } \\
\text { Mean } \pm \text { SD }\end{array}$ & $\begin{array}{l}\text { Day 21 } \\
\text { Mean } \pm \text { SD }\end{array}$ & $\begin{array}{l}\text { Day 28 } \\
\text { Mean } \pm \text { SD }\end{array}$ \\
\hline Control & $64 \pm 1.4$ & $45 \pm 1.1$ & $56.83 \pm 1.5$ & $56.67 \pm 1.3$ & $53.50 \pm 2.0$ \\
Treat 1 & $62.0 \pm 2.1$ & $33.67 \pm 2.4^{* * *}$ & $32.50 \pm 2.2^{* * *}$ & $31.50 \pm 2.3^{* * *}$ & $31.33 \pm 2.5^{* * *}$ \\
Treat 2 & $55.33 \pm 2.7$ & $24.67 \pm 3.1^{* * * ! ! !}$ & $18.50 \pm 3.3^{* * * ! ! !}$ & $20.33 \pm 3.2^{* * * ! ! !}$ & $20.00 \pm 2.8^{* * * ! ! !}$ \\
\hline
\end{tabular}

Table 3 Activity of tomato juice on elevated plus maze test (time spend in open arm)

\begin{tabular}{llllll}
\hline Groups & $\begin{array}{l}\text { Baseline } \\
\text { Mean } \pm \text { SD }\end{array}$ & $\begin{array}{l}\text { Day 7 } \\
\text { Mean } \pm \text { SD }\end{array}$ & $\begin{array}{l}\text { Day 14 } \\
\text { Mean } \pm \text { SD }\end{array}$ & $\begin{array}{l}\text { Day 21 } \\
\text { Mean } \pm \text { SD }\end{array}$ & $\begin{array}{l}\text { Day 28 } \\
\text { Mean } \pm \text { SD }\end{array}$ \\
\hline Control & $76 \pm 1.5$ & $95 \pm 1.1$ & $91.83 \pm 1.6$ & $88.33 \pm 1.4$ & $85.50 \pm 1.3$ \\
Treat 1 & $85.83 \pm 1.2$ & $158.33 \pm 2.2^{* * *}$ & $187.50 \pm 3.0^{* * *}$ & $220.50 \pm 1.1^{* * *}$ & $193.83 \pm 1.7^{* * *}$ \\
Treat 2 & $88.33 \pm 1.7$ & $159.17 \pm 2.1^{* * *}$ & $232.17 \pm 2.4^{* * * ! ! !}$ & $264.17 \pm 2.6^{* * * ! ! !}$ & $233.0 \pm 1.5^{* * * ! ! !}$ \\
\hline
\end{tabular}

Table 4 Activity of tomato juice on cage crossing test

\begin{tabular}{llllll}
\hline Groups & $\begin{array}{l}\text { Baseline } \\
\text { Mean } \pm \text { SD }\end{array}$ & $\begin{array}{l}\text { Day 7 } \\
\text { Mean } \pm \text { SD }\end{array}$ & $\begin{array}{l}\text { Day 14 } \\
\text { Mean } \pm \text { SD }\end{array}$ & $\begin{array}{l}\text { Day 21 } \\
\text { Mean } \pm \text { SD }\end{array}$ & $\begin{array}{l}\text { Day 28 } \\
\text { Mean } \pm \text { SD }\end{array}$ \\
\hline Control & $32.00 \pm 2.6$ & $30 \pm 2.1$ & $26.83 \pm 2.5$ & $30.00 \pm 3.0$ & $28.50 \pm 2.3$ \\
Treat 1 & $28.50 \pm 2.0$ & $13.33 \pm 1.6^{* * *}$ & $11.17 \pm 1.4^{* * *}$ & $13.17 \pm 1.5^{* * *}$ & $10.50 \pm 1.8^{* * * *}$ \\
Treat 2 & $28.67 \pm 1.5$ & $10.83 \pm 1.1^{* * *}$ & $11.00 \pm 2.0^{* * *}$ & $10.33 \pm 1.21^{* * *}$ & $10.00 \pm 1.4^{* * * *}$ \\
\hline
\end{tabular}

Data obtained from these different test were combined and data was analyzed which offered a complete description of individual behavioral profiles. ${ }^{19}$ Our study revealed the anxiolytic activity of tomato juice suggesting that intake of tomato juice alleviates anxiety. A variety of bioactive ingredients were found in tomato juice such as gamma-aminobutyric acid (GABA), lycopene, 13-oxo-9,11octadecadienoic acid (13-oxo-ODA), and esculeoside A. These all ingredients tend to have different physical and psychological health benefits. For example, GABA reduces psychological stress and lowers blood pressure. ${ }^{12}$ Majority of anxiolytic drugs produced effect by binding to GABA receptor, causing opening of chloride channel and hyperpolarization. ${ }^{20}$ Tomato juice might produce the anxiolytic effect because of presence of GABA. Besides that lycopene was predominant carotenoid in tomatoes and due to its anti-oxidative effects showed 
anxiolytic activity, i.e. relieving the symptoms of anxiety. In our study we used tomato juice instead of tomatoes it had several advantages i.e. increased levels of lycopene could be extracted thus an increased

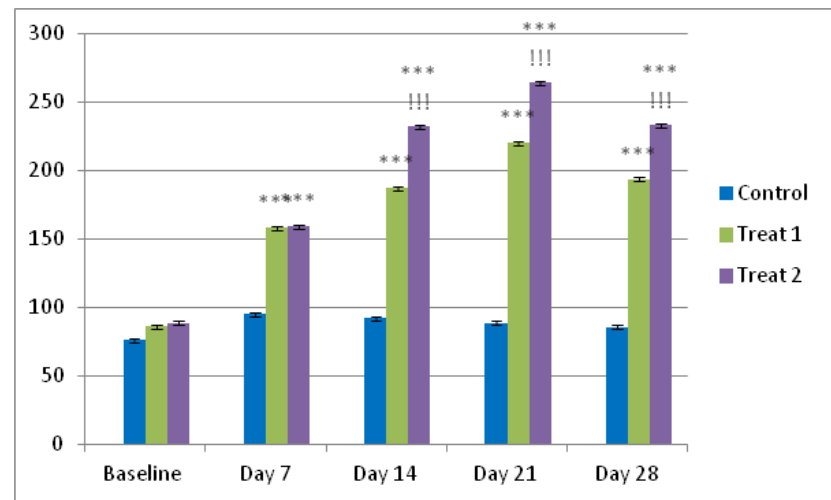

Figure 3 Activity of tomato juice on elevated plus maze.

\section{Conclusion}

Intake of tomato juice alleviates anxiety due to presence of an important carotenoid i.e. Lycopene which is mainly responsible for most of the health benefits of tomato juice. It has a high antioxidant capacity which tends to reduce anxiety and relief the symptoms of anxiety. Further work needs to be done to evaluate the exact mechanism of action by which lycopene produces this effect.

\section{Acknowledgements}

None.

\section{Conflict of interest}

The author declares that there is no conflict of interest.

\section{References}

1. Mirza I, Jenkins R. Risk factors, prevalence, and treatment of anxiety and depressive disorders in Pakistan: systematic review. BMJ. 2004;28(7443):794.

2. http://displus.sk/DSM/subory/dsm3.pdf

3. Sauter SL, Murphy LR, Hurrell JJ. Prevention of work-related psychological disorders: A national strategy proposed by the National Institute for Occupational Safety and Health (NIOSH). Am Psychol. 1990;45(10):1146.

4. Stallman HM. Psychological distress in university students: A comparison with general population data. Australian Psychologist. 2010;45(4):249-257.

5. Vos T, Flaxman AD, Naghavi M, et al. Years lived with disability (YLDs) for 1160 sequelae of 289 diseases and injuries 1990-2010: a systematic analysis for the Global Burden of Disease Study 2010. Lancet. 2013;380(9859):2163-2196.

6. Black DW, Grant JE. DSM-5® guidebook: the essential companion to the diagnostic and statistical manual of mental disorders. American Psychiatric Pub. 2014.

7. Garay RP, Samalin L, Hameg A, et al. Investigational drugs for anxiety in patients with schizophrenia. Expert opin Investig Drugs. 2015;24(4):507-517. antioxidant capacity and eventually more efficacious anxiety reducing activity was observed.

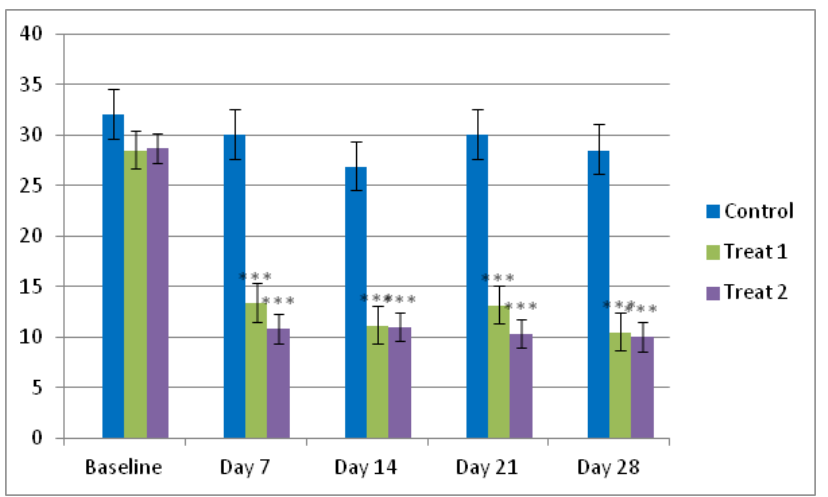

Figure 4 Activity of tomato juice on cage crossing.

8. Etkin A, Prater KE, Schatzberg AF, et al. Disrupted amygdalar subregion functional connectivity and evidence of a compensatory network in generalized anxiety disorder. Arch Gen Psychiatry. 2009;66(12):13611372 .

9. Zung WW. A rating instrument for anxiety disorders. Psychosomatics. 1971;12(6):371-379.

10. Bhowmik D, Kumar KS, Paswan S, et al. Tomato-a natural medicine and its health benefits. Journal of Pharmacognosy and Phytochemistry. 2012;1(1):33-43.

11. Nasir MU, Hussain S, Jabbar S. Tomato processing, lycopene and health benefits: A review. Science Letters. 2015;3(1):1-5.

12. Hirose A, Terauchi M, Tamura M, et al. Tomato juice intake increases resting energy expenditure and improves hypertriglyceridemia in middle-aged women: an open-label, single-arm study. Nutrition journal. 2015;14(1):34.

13. Mohammed S. Anticoagulant activity of fruits of Solanum lycopersicum (tomato) in albino Wistar rats. Natural Products Chemistry \& Research, 3rd International Conference and Exhibition on Pharmacognosy, Phytochemistry \& Natural Products; 2015.

14. File SE, Wardill AG. Validity of head-dipping as a measure of exploration in a modified hole-board. Psychopharmacology. 1975;44(1):53-59.

15. Hall C, Ballachey EL. A study of the rat's behavior in a field. A contribution to method in comparative psychology. USA; University of California Publications in Psychology. 1932.

16. Bailey KR, Crawley JN. Anxiety-related behaviors in mice. 2nd ed. CRC Press/Taylor and Francis; 2009.

17. Carobrez AP, Bertoglio LJ. Ethological and temporal analyses of anxiety-like behavior: the elevated plus-maze model 20 years on. Neurosci Biobehav Rev. 2005;29(8):1193-1205.

18. Belzung C, Griebel G. Measuring normal and pathological anxiety-like behaviour in mice: a review. Behav Brain Res. 2001;125(1):141-149.

19. Bourin M, Petit Demoulière B, Nic Dhonnchadha B, et al. Animal models of anxiety in mice. Fundam Clin Pharmacol. 2007;21(6):567574.

20. Hwang ES, Stacewicz Sapuntzakis M, Bowen PE. Effects of heat treatment on the carotenoid and tocopherol composition of tomato. $J$ Food Sci. 2012;77(10):C1109-C1114. 